Tạp chí Y Dược Lâm Sàng 108, 9 (số 1), pp. 82-87.

6. Celikyay, Koner, Celikyay, et al. (2013). "Frequency and imaging findings of variations in human aortic arch anatomy based on multidetector computed tomography data". Clin Imaging, 37(6), pp. 1011-9.

7. Evangelista Arturo, Isselbacher Eric M.,
Bossone Eduardo, Gleason Thomas G., Eusanio Marco Di, et al. (2018), "Insights From the International Registry of Acute Aortic Dissection". Circulation, 137 (17), pp. 1846-1860.

8. Viscomi S.G. (2008), "Chapter 5: Computed tomography",in: J.S. Conselli, S.A.Lemaire, Aortic Arch Surgery, Blackwell, West Sussex-UK, pp. 39-57.

\title{
NGHIÊN CỨU BÀO CHẾ VIÊN NANG TỪ BÀI THUỐC LƯC VI HOÀN
}

\author{
Nguyễn Đăng Thoại ${ }^{1}$, Nguyễn Mạnh Huy ${ }^{1}$, Khưu Mỹ Lệ
}

TÓM TẮT

Mục tiêu: Bào chế Luc vị hoàn ở dang thuốc viên nang để chuẩn hóa liều dùng và thuẩn tiện khi sử dụng. Đối tượng và phương pháp: Chế biến nguyên liệu bằng phương pháp nấu cao hoă̆c xay bột. Công thức viên nang cứng được xây dựng và chọn lựa dưa vào đô ẩm, tỷ trọng biểu kiến và độ trơn chảy của khối bột đóng nang và các thiết bị tương ứng. Kết quả: Đã bào chếđược viên nang lục vị với liều dùng quy đổi là 3 viên/lần, ngày uống 2 lần. Kết quả định tính cho thấy viên nang lục vị hoàn có phản ứng dương tính với các thuốc thử ứng với thành phần dược liệu và trên sắc ký đồ có các vết cùng giá trị $R_{f}$ và cùng màu sắc với các vết trên sắc ký đồ của dung dịch đối chiếu. Viên đạt yêu cầu về độ đồng đều khối lượng, độ rã theo quy định của viên nang. Kết luận: Viển nang chứa cao luc vi hoàn đã được bào chế đat yêu cầu về chất lượng của viên nang, có tác dụng bồi bổ khí huyết, dùng điêu trị hỗ trơ cho người đau lưng, nhức mỏi đâu gối, hoa mắt, chóng mặt, sử dụng thuân tiên.

Từ khóa: Lục vị hoàn, bồi bổ khí huyết, đau lưng, nhức mỏi đầu gối,hoa mắt.

\section{SUMMARY}

\section{PREPARATION OF CAPSULE CONTAINING} EXTRACT FROM SIX TYPES OF MEDICINAL HERBS

Objectives: To prepare Luc vi hoan in capsule form to standardize dosage and convenient to use. Materials and methods:The herb was extracted by hot water orground into powder. Moisture, density and smoothness of the powder were analized to select hard capsule formulations. Results: Luc vi capsules were prepared with an equivalent dose of 3 capsules/time, twice a day. Starch was added to form one capsule. As a result, capsules had a positive reaction to the reagents. On the chromatogram, there were traces of the same $R_{\mathrm{f} v a l u e}$ and the same color as those on the chromatogram of reference medicinal herbs. Luc vi hoan capsules meet the requirements of mass uniformity and disintegration prescribed in Vietnamese pharmacopoeia. Conclusions: Luc vi

${ }^{11}$ Trường $Đ H$ Y khoa Phạm Ngoc Thạch

Chịu trách nhiệm chính: Nguyển Đăng Thoại

Email: thoaind@pnt.edu.vn

Ngày nhận bài: 2/1/2021

Ngày phản biên khoa hoc: 7/2/2021

Ngày duyệt bài: 3/3/2021 hoan capsuleswere prepared and the quality was investigated. It has the effect of nourishing blood, supporting treatment for people with back pain, knee pain, dizziness. Besides, capsule form is convenient for patients.

Keywords: Luc vi hoan, nourishing blood, back pain, knee pain, dizziness.

\section{I. ĐẶT VẤN ĐỀ}

Lục vị hoàn là bài thuốc nổi tiếng của y học cổ truyền Việt Nam, có trong bộ sách Hải Thượng y tông tâm lĩnh của Hải Thượng Lãn Ông Lê Hữu Trác. Trải qua hàng trăm năm, Lục vị hoàn được xem là một trong những bài thuốc căn bản của Đông y có giá trị cao trong chữa bệnh. Ngày nay, Lục vị hoàn có tên trong Danh mục thuốc thiết yếu của Bộ $Y$ tế ban hành vào năm 2018. Bài thuốc Lục vị hoàn gôm các vị thuốc: Thục địa, sơn thù, sơn dược, mẫu đơn, trạch tả, phục linh được bào chế dưới dạng viên hoàn cứng, đóng chai. Để góp phần chuẩn hóa liều dùng và tạo sự tiện dụng cho người bệnh trong đời sống hiện đại ngày nay, chúng tôi nghiên cứu hiện đại hóa bài thuốc Lục vị hoàn ở dạng viên nang cứng với số viên tối thiểu của liều sử dụng.

\section{II. ĐỐl TƯỢNG VÀ PHƯƠNG PHÁP NGHIÊN CỨU \\ 2.1. Đối tượng nghiên cứu}

2.1.1. Nguyên liệu. Các dược liệu được sấy khô ở $50^{\circ} \mathrm{C}$. Tất cả các dược liệu đều đạt tiêu chuẩn Dược điển Việt Nam V.

- Thục địa(Rehmania glutinosa Libosch). Bộ phận dùng: Rễ (Radix Rehmanniae glutinosae praeparata)

- Sơn thù (Cornus officinalis Sieb. et Zucc). Bộ phận dùng: Quả (Fructus Corni officinalis)

- Hoài sớn (củ mài, sớn dược) (Dioscorea persimilis Prain et Burk). Bộ phận dùng: Rễ củ (Tuber Dioscoreae persimilis)

- Mẫu đơn bì (Paeonia suffruticosa Andr). Bô phận dùng: Vỏ rễ (Cortex Paeoniae suffruticosae)

Trạch tả (Alisma plantago-aqulica L. var. orientale Samuels). Bộ phận dùng: Rễ củ (Rhizoma Alismatis) 
- Phục linh (Poria cocos Wolf). Bộ phận dùng: Toàn bộ nấm (Poria)

\subsubsection{Dụng cụ, trang thiêt bị, hóa chât}

- Máy trộn RT-70.

- Máy đo tỷ trọng bột JV 200i (Copley - Anh).

- Máy đo tốc độ chảyBEP2 (Copley - Anh). 100 lố.

- Máy đóng nang thủ công: $\mathrm{CN}-100 \mathrm{CL}$, khuôn

- Tủ sấy Memmert.

- Rây 2 mm.
- Cân phân tích Shimadzu.

- Bản mỏng silica gel $F_{254}$ tráng sẵn (Merck, Đức).

- Hóa chất, dung môi đạt tiêu chuẩn quy định.

- Một số dựng cụ thí nghiêm thông thường khác.

\subsection{Phương pháp nghiên cứu}

2.2.1. Công thức pha chế. Tiến hành xây dựng công thức khối thuốc khoảng 500 mg. Hàm lương cao và bôt dược liệu được quy về độ ẩm $0 \%$. Thành phần công thức và tî lệ của viên nang lục vị hoàn được trình bày trong Bảng 1.

Bảng 1. Thành phần công thức điều chế viên nang lực vị hoàn

\begin{tabular}{|c|c|c|c|c|c|}
\hline Thành phân (1 viên, mg) & $\begin{array}{c}\text { Công thức } \\
\mathbf{1}\end{array}$ & $\begin{array}{c}\text { Công thức } \\
\mathbf{2}\end{array}$ & $\begin{array}{c}\text { Công thức } \\
\mathbf{3}\end{array}$ & $\begin{array}{c}\text { Công } \\
\text { thức } \mathbf{4}\end{array}$ & $\begin{array}{c}\text { Công } \\
\text { thức } \mathbf{5}\end{array}$ \\
\hline Cao khô thục địa & 96 & 96 & 96 & 96 & 96 \\
\hline Cao khồ sơn thù & 48 & 48 & 48 & 48 & 48 \\
\hline Bột hoài sơn & 48 & 48 & 48 & 48 & 48 \\
\hline Bột mâu đơn bì & 36 & 36 & 36 & 36 & 36 \\
\hline Cao khố Trạch tả & 36 & 36 & 36 & 36 & 36 \\
\hline Bột phục linh & 36 & 36 & 36 & 36 & 36 \\
\hline Tinh bột & 160 & 70 & 60 & 50 & 0 \\
\hline Avicel & 0 & 90 & 100 & 110 & 160 \\
\hline Talc & 20 & 20 & 20 & 20 & 20 \\
\hline
\end{tabular}

\subsubsection{Chế biến nguyên liệu}

- Xay bột: Hoài sơn: 60g; Phục linh: 45g; Đơn bì: $100 \mathrm{~g}$

+ Dược liệu được rửa sạch, sây khô đến độ ẩm khoảng $7 \%$.

+ Trộn đều 3 dược liêu.

+ Xay thành bộtmịn bằng máy xay RT-70.

- Nấu cao

Các dước liệu: thục đia, sơn thù, trạch tảđược chế biến bằng phương pháp nấu cao.

- Rửa sach các dước liệu.

- Cho dược liệu vào nồi, đổ nước vào ngập dược liêu.

- Nấu thành 3 đợt

+ Đợt 1.Đun sôi trong 3 giờ, thu dịch chiết 1

+ Đợt 2.Đun sôi trong 2 giờ, thu dịch chiết 2

+ Đợt 3. Đun sôi trong 1 giờ, thu dịch chiết 3

- Gộp 3 đợt dịch chiết, lọc qua vải phin, cô cách thủy đến khi cao còn $30 \%$ ẩm.

2.2.3. Bào chế viên nang cứng. Quy trình bào chế viên nang tô mộc, qua các bước sau:

- Vệ sinh dụng cụ pha chế bằng cồn 96.

- Cân cao, bột dược liệu, tinh bột, avicel.

- Cho nguyền liệu vào máy xay RT-70, đậy kín nắp.

- Nhào trôn.

- Xát hạt qua rây $2 \mathrm{~mm}$.

- Sây khô trong tủ sây.

- Sữa hạt qua rây $1 \mathrm{~mm}$.

- Trôn hoàn tất với talc.

2.2.4. Khảo sát tính chất của khối bột đóng nang. Sau khi trộn, tiến hành khảo sát đặc tính của các khối bột tạo ra từ 5 công thức qua các chỉ tiêu:

Độ ẩm: Thực hiện trong tủ sây với các thông số:

- Lương cân: $1 \mathrm{~g}$

- Nhiệt độ sấy: $105^{\circ} \mathrm{C}$

- Yêu câu: độ ẩm < 5\%

Tỷ trọng biểu kiến: Bằng máy đo tỷ trọng.

- Tính toán theo công thức: $P=M / V$

- P: Tỷ trọng biểu kiến của hạt

- M: Khối lượng của hạt

- V: Thể tích biểu kiến của hat

Đô chảy: Thực hiên bằng máy đo tốc độ chảy - Lượng hạt mỗi lần thử là 50 - 100g

Tốc độ chảy = khối lượng hạt $(\mathrm{g}) /$ thời gian chảy hết khối hạt (s)

\subsubsection{Kiểm nghiêm viên nang lục vị hoàn}

Độ đồng đều khối lượng. Lấy 20 viên nang lục vị hoàn, thử độ đồng đều khối lượng của viên nang lục vị hoàn theo phương pháp 2 , Phụ lục 11.3, DDVN V.

Yêu cầu: chênh lệch khối lượng của từng viên nang so với khối lượng trung bình là $\pm 7,5 \%$.

Độ rã. Lây 6 viển nang lục vị hoàn, thử độ rã của viên nang lục vị hoàn theo Phụ lục 11.6, DDVN V.

Yêu cầu: Cả 6 viên thử nghiệm đều rã. Nếu có 1 đến 2 viên không rã, lặp lại phép thử với 12 viên khác. Mẫu thử đạt yêu cầu nếu không dưới 16 trong số 18 viên thử rã.

Định tính. Định tính bằng sắc ký lớp mỏng 


\section{- Đinh tính hoài sơn}

Phương pháp sắc ký lớp mỏng (Phụ lục 5.4, $\mathrm{D} \oplus \mathrm{VN} V$ ). Bột dược liệu được thay bằng bột đóng nang.

Yêu cầu: Dưới ánh sáng thường hoặc ánh sáng tử ngoại 365 nm, trên sắc ký đồ của dung dịch thử phải có các vết có cùng màu và giá trị $R_{f}$ với các vết trên sắc ký đồ của dung dịch đối chiếu.

\section{- Định tính sơn thù}

Phương pháp sắc ký lớp mỏng (Phụ lục 5.4, DĐVN V). Bột dược liệu được thay bằng bột đóng nang.

Yêu cầu: Dưới ánh sáng ban ngày, trên sắc ký đồ của dung dịch thử phải xuất hiện vết màu đỏ tím có cùng màu và giá trị $R_{\mathrm{f}}$ với các vết trên sắc ký đồ của dung dịch đối chiếu. Dưới ánh sáng tử ngoại ở bước sóng $365 \mathrm{~nm}$, trên sắc ký đồ của dung dịch thử phải có vết có huỳnh quang màu vàng cam có cùng màu và giá trị $\mathrm{R}_{\mathrm{f}}$ với các vết trên sắc ký đồ của dung dịch đối chiếu.

Định lượng. Xác định hàm lượng cao tan trong cồn $70 \%$ của dược liệu hoài sơn, sơn thù.

Tiến hành theo Phụ lục 12.10, DĐVN V.

Yêu cầu: Hàm lượng này không dưới 100 mg cao cho 1 viên nang (quy về $0 \%$ ẩm).

Bảo quản. Viên nang được đóng chai, đậy kín. Tránh ánh sáng, nhiệt độ bảo quản không quá $25^{\circ} \mathrm{C}$ và độ ẩm $<70 \%$.

\section{KẾT QUẢ NGHIÊN CứU}

3.1. Thành phần công thức của viên nang lục vị hoàn. Thành phần công thức của viên nang lục vị hoàn cho lô 1.000 viên được trình bày trong Bảng 2 . Hàm lượng cao và bột dược liệu được quy về đô ẩm $0 \%$.

Bảng 2. Thành phần công thức của viên nang lục vị hoàn cho lô 1.000 viên

\begin{tabular}{|c|c|c|c|}
\hline STT & Thành phân & $\begin{array}{c}\text { Công thức } \\
\text { cho 1 viên } \\
(\mathbf{m g})\end{array}$ & $\begin{array}{c}\text { Công } \\
\text { thức cho } \\
\mathbf{1 . 0 0 0} \\
\text { viên } \mathbf{( g )}\end{array}$ \\
\hline 1 & Cao khô thục địa & 96 & 96 \\
\hline 2 & Cao khô sơn thù & 48 & 48 \\
\hline 3 & Bột hoài sơn & 48 & 48 \\
\hline 4 & Bột mâu đơn bì & 36 & 36 \\
\hline 5 & Cao khố Trạch tả & 36 & 36 \\
\hline 6 & Bột phục linh & 36 & 36 \\
\hline 7 & Tinh bột & 60 & 60 \\
\hline 8 & Avicel & 100 & 100 \\
\hline 9 & Talc & 20 & 20 \\
\hline
\end{tabular}

3.2. Tính chất của khối bột đóng nang

Tính chất của khối bột của viên nang lục vị hoàn được trình bày trong Bảng 3.

Bảng 3. Tính chất của khối bôt đóng nang

\begin{tabular}{|c|c|c|c|c|c|}
\hline Tính chất & CT1 & CT2 & CT3 & CT4 & CT5 \\
\hline Độ ấm $(\%)$ & $6,10 \pm 2,4 \%$ & $5,35 \pm 4,1 \%$ & $4,89 \pm 3,9 \%$ & $4,61 \pm 3,5 \%$ & $4,58 \pm 3,7 \%$ \\
\hline $\begin{array}{c}\text { Tỷ trọng biểu } \\
\text { kiến }(\mathrm{g} / \mathrm{ml})\end{array}$ & $0,42 \pm 3,1 \%$ & $0,51 \pm 3,7 \%$ & $0,80 \pm 1,5 \%$ & $0,79 \pm 4,6 \%$ & $0,76 \pm 1,1 \%$ \\
\hline Độ chảy $(\mathrm{g} / \mathrm{s})$ & $1,23 \pm 4,3 \%$ & $3,29 \pm 4,8 \%$ & $9,56 \pm 2,7 \%$ & $8,13 \pm 1,8 \%$ & $7,04 \pm 2,6 \%$ \\
\hline
\end{tabular}

Chọn công thức 3 để tiếp tục nghiên cứu vì có độ ẩm phù hợp và độ chảy tốt hơn các công thức còn lai.

\subsection{Quy trình bào chế}

Quy trình bào chế viên nang lục vị hoàn lô 1.000 viên qua các bước sau:

- Vệ sinh dụng cụ pha chế bằng cồn $96 \%$.

- Cân cao, bột dược liệu, tinh bột, avicel với lượng đủ 1.000 viên.

- Trộn đều bằng tay, cho nguyên liệu vào máy xay RT-70, đậy kín nắp.

- Nhào trộn trong 2 phút, tạo cốm ướt.

- Xát hạt qua rây $2 \mathrm{~mm}$.

- Sấy khô 6 giờ trong tủ sấy ở $50^{\circ} \mathrm{C}$.

- Sửa hat qua rây $1 \mathrm{~mm}$.

- Sấy tiếp ở $50^{\circ} \mathrm{C}$ cho đến khi đạt độ ẩm $7 \%$.

- Trộn hoàn tất với talc.

- Đóng nang bằng máy vô nang $\mathrm{CN}-100 \mathrm{CL}$, khuôn 100 lỗ.

\section{Chọn cỡ nang}

- Tỉ trọng bột $\mathrm{d}_{b}=0,80 \mathrm{~g} / \mathrm{ml}$
- Khối lượng bột thuốc trong 1 viên là $m=$ 480mg

- Vậy thể tích bột $=0,60 \mathrm{ml}$

- Dung tích 0,60 ml gần với dung tích nang số $0(0,67 \mathrm{ml})$. Do đó, đề tài chọn nang số 0 để đóng nang.

Đóng nang. Đóng nang bằng máy vô nang $\mathrm{CN}-100 \mathrm{CL}$, khuôn 100 lỗ, hiệu suất đóng nang là 96\%. Sau khi đóng nang, nang được đánh bóng và tiến hành kiểm nghiệm.

3.4. Kiểm nghiệm viên nang. Viên nang cứng số 0 , một đâu tím, một đầu trắng. Bột thuốc trong nang có màu nâu nhạt, vị đặc trưng.

Đồng đều khối lượng. Khối lượng trung bình của viên nang lục vị hoàn là 484,2 mg \pm $3,2 \%$. Tất cả 20 viên đem thử đều có chênh lệch khối lượng so với khối lượng trung bình $<7,5 \%$.

Độ rã. Thời gian rã trung bình là 19,6 phút \pm $5 \%<30$ phút. Tất cả 6 viên đem thử đều đạt yêu cầu về độ rã.

Định tính. Định tính bằng sắc ký lớp mỏng 
- Hoài sơn: Sắc ký đồ của dung dịch thử có các vết cùng giá trị $R_{f}$ và cùng màu sắc với các vết trên sắc ký đồ của dung dịch đối chiếu.

- Sơn thù: Dưới ánh sáng ban ngày, trên sắc ký đồ của dung dịch thử xuất hiện vết màu đỏ tím có cùng màu và giá trị $R_{f}$ với các vết trên sắc ký đồ của dung dịch đối chiếu. Dưới ánh sáng tử ngoại ở bước sóng 365 nm, trên sắc ký đồ của dung dịch thử xuất hiện vết có huỳnh quang màu vàng cam có cùng màu và giá trị $R_{f}$ với các vết trên sắc ký đồ của dung dịch đối chiếu.

Định lượng. Hàm lượng cao tan trong cồn $70^{\circ}$ là $121 \mathrm{mg} \pm 4,5 \%>100 \mathrm{mg}$ cao cho 1 viên nang (quy về $0 \%$ ẩm).

\section{BÀN LUẬN}

Với 6 thành phần dược liệu khác nhau, công thức bào chế của lục vị hoàn có sự phối hợp giữa cao chiết và bột dược liệu nhằm tối ưu lượng dược liệu sử dụng.

\section{KẾT LUÂNN}

- Đã xác định tỷ lệ dược liệu dùng nấu cao và xay bột phù hợp.

- Đã chế biến được cao dược liệu, bột mịn dược liệu.

- Xây dựng được công thức và bào chế viên nang lục vị hoàn.

- Kiểm nghiệm viên nang lục vị hoàn đạt yêu cầu về chất lượng của viên nang.

KIẾN NGH!
- Tối ưu hóa công thức bào chế viên nang lục vị hoàn.

- Tiêu chuẩn hóa nguyên liệu và thành phẩm dựa trên các phương pháp hiện đại.

- Nghiên cứu độc tính bất thường trên chuột và thử nghiệm lâm sàng.

- Nghiên cứu độ ổn định của chế phẩm.

- Tiến hành sản xuất ở quy mô pilot.

\section{TÀI LIỆU THAM KHẢO}

1. Bộ Y tế (2018). Danh mục thuốc thiết yếu.

2. Hải Thượng $Y$ Tông Tâm Lĩnh, Lê Hữu Trác, Hải Thượng Lãn Ong, Nhà xuất bản $Y$ học, 2008, $1-17$.

3. Lee HyunKyung, Cha Hwa Jun Cha, Poria cocos. Wolf extracts represses pigmentation in vitro and in vivo, Cellular and molecular biology 64 (5), 2018, $80-84$.

4. Huang Jun, Zhang Yiwei, Gao Qinghan, Yin Lei, Quan Hongfeng, Chen Rong, Fu Xueyan, Lin Dingbo, Ethnopharmacology, phytochemistry, and pharmacology of Cornus officinalis Sieb. et Zucc, Journal of Ethnopharmacology, Vol 213, $2018,280-301$.

5. Liu S, Li Y, Yi F, Liu Q, Chen N, He X, He C, Xiao P. Resveratrol oligomers from Paeonia suffruticosa protect mice against cognitive dysfunction by regulating cholinergic, antioxidant and anti-inflammatory pathways. Journal of Ethnopharmacol, Vol 260, 2020.

6. Jin $Q$, Zhang J, Hou J, Lei $M$, Liu $C$, Wang $X$, Huang $Y$, Yao S, Hwang BY, Wu W, Guo D. Novel $\mathrm{C}-17$ spirost protostane-type triterpenoids from Alisma plantago-aquatica with antiinflammatory activity in Caco-2 cells. Acta Pharmaceutica Sinica B. 9(4), 2019, $809-818$.

\section{TIẾN TRIỂN CỦA TỔN THƯƠ'NG THÂ̂N CẤP Ở BỆNH NHÂN NGộ ĐộC CẤP TẠI TRUNG TÂM CHỐNG ĐộC, BỆNH VIỆN BẠCH MAI}

\section{TÓM TẮT}

Mục tiêu: Đánh giá tiến triển của tổn thương thận cấp và một số yếu tố liên quan ở bệnh nhân ngộ độc cấp". Đối tượng và phương pháp: Nghiên cứu mồ tả tiến cứu trên 73 bệnh nhân ngộ độc cấp có tổn thương thận cấp điêu trị tại Trung tâm Chống độc, bênh viện Bạch Mai từ tháng 7/2019 đến 7/2020. Các biến số nghiên cứu được thu thập theo mâuu bệnh án thống nhất, tổn thương thận cấp được chẩn đoán khi khi creatinin máu $\geq 130 \mu \mathrm{mol} / / \mathrm{l}$ và được chia ra 3 mức

*Trung Tâm Chống Độc - Bệnh viện Bạch Mai Chịu trách nhiệm chính: Đặng Thị Xuân Email: xuandangthi17@gmail.com Ngày nhận bài: 4.01.2021 Ngày phản biện khoa học: 2.3.2021 Ngày duyệt bài: 15.3.2021

\section{Đặng Thị Xuân*}

độ nặng theo KDIGO. Kết quả: Tỉ lệ bệnh nhân có tổn thương thân tại thời điểm nhập viện mức độ 1 là $24,7 \%$, mức độ 3 là $17,8 \%$ và thấp nhất là mức độ 2 là $9,6 \% ; 47,9 \%$ bệnh nhân chưa có tổn thương. Có 60,3\% bệnh nhân có tổn thương thận nặng lên trong quá trình điều trị. $60,3 \%$ bệnh nhần có chức năng thận hồi phục khi ra viện, tỉ lệ hồi phục cao nhất là nhóm tổn thương thận mức độ 1 khi vào viện (100\%). Ngộ độc càng nặng (theo thang điểm PSS) thì tỉ lệ tôn thương thận càng nặng. Bệnh nhân sống có tỉ lệ thận hồi phục cao hơn so với nhóm tử vong. Kết luận: Mức độ nặng tổn thương thận lúc vào viện ít liên quan với mức độ nặng của tôn thương thận trong quá trình điều trị và tiên lượng hồi phục chức năng thận.

Tư khóa: Ngộ độc cấp, tổn thương thận cấp.

\section{SUMMARY}

EVOLUTION OF ACUTE KIDNEY INUURY IN

PATIENTS WITH ACUTE POISONING AT POISON 